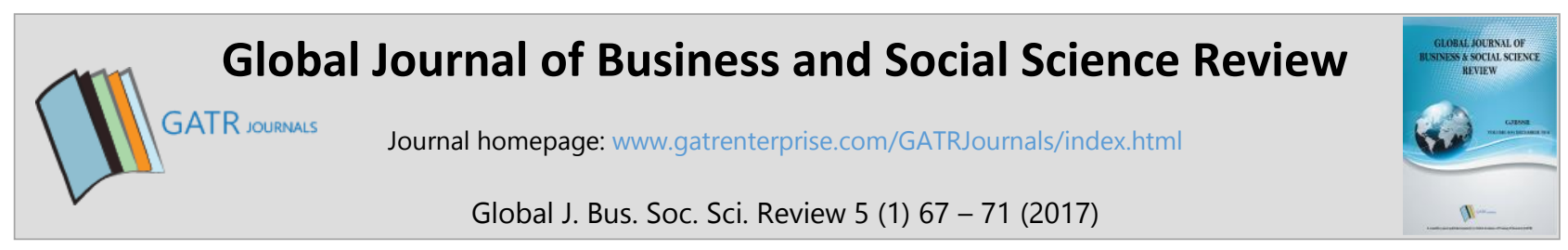

\title{
The Use of Electronic Medical Records as Evidence in the Criminal Process in Indonesia
}

\author{
Anny Retnowati * \\ Faculty of Law, Universitas Atmajaya Yogyakarta, Mrican Baru 28, 55281, Yogyakarta, Indonesia
}

\begin{abstract}
Objective - This article deals with the prospective use of electronic medical records as instruments of evidence in criminal procedural law in Indonesia. In particular, this article concerns the usefulness of these records in criminal cases.

Methodology/Technique - This article applies doctrinal research involving a consideration of the relevant legal norms. Hence, a qualitative method is used to analysis the relevant data.

Findings - The study suggests the legal basis in article 184 of the KUHAP should be revised by adding electronic evidence so that the use of electronic medical records can be used as evidence in the criminal process in Indonesia.

Novelty - The study tries to provide ways to enhance the evidencing in criminal process.

Type of Paper: Empirical.
\end{abstract}

Keywords: Electronic Medical Record; Criminal Process; Evidence; Indonesia.

JEL Classification: K14, O33.

\section{Introduction}

Health service is not separated from the development of science and technology, as medical record can also be created electronically. Technology can be thought of as an extension of the human body (Van Persoan) with the use of technology, technical ease can be obtained. For an example, our handwritten articles might be difficult to read to others, that is why a typewriter or computer with printer is much better. Now these processes are even more advanced and efficient since writing can be stored in a disk or other digital medias. It is easier to edit, or re-print, resulting in less errata (handwriting era) or typo (typewriter era). ${ }^{1}$ This is in line with Wisnubroto (2010), who said that science and technology development has reached an ultimate stage. One product of science and technology that has become a symbol of the development in science and technology is IT (Information Technology). This development has changed the system from manual to digital/electronic system in a revolutionary way. ${ }^{2}$ Hatta (1995) also argued, however, that sooner or later, whether we like it or

\footnotetext{
*Paper Info: Revised: September, 2016

Accepted: January, 2017

* Corresponding author:

E-mail: hukum@mail.uajy.ac.id

Affiliation: Faculty of Law, Universitas Atmajaya Yogyakarta, Indonesia

${ }^{1}$ Abdul Wahid and Mohammad Labib, 2005, Kejahatan Mayantara, Refika Aditama, Bandung, page 15

${ }^{2}$ Alosius Wisnubroto, 2010, Rekonseptualisasi Hukum Pidana Indonesia dalam Menghadapi Kejahatan yang berbasis Tehnologi

Telematika, ringkasan Desertasi, Program doktor, Semarang, page 4
} 
not, the disparities caused by ICT (Information and Communication Technologies) is inevitable, and the disparities will be wider and harder to follow. It is because the ICT revolution never walks backward that a paradigm shift becomes inevitable. ${ }^{3}$ The technology was initially developed to assist people in carrying out their activities however, control of the use of technology remains entirely in the hands of human. ${ }^{4}$ As we enter the 21st century, the terminology used in technology in the medical field is the Electronic Health Record (electronic health record-RKE). This terminology is included in the standard details developed in the USA. Electronic Health Record is regarded as a future term, describing the system that will support all types of service providers in all forms of service, including for individuals who will use the data records/personal health information. Since as early as 2006, the personal health record has been used free of charge to the public as a collaboration between the American Health Information Management Association and the American Medical Informatics Association. ${ }^{5}$ Based on the background above, the main focus in this research is formulated as follows:

1. Is Electronic Medical Record included as evidence in criminal procedural law in Indonesia?

2. How powerful is an Electronic Medical Record as evidence in criminal procedural law in Indonesia?

\section{Theoretical Review}

Criminal Code Procedures (KUHAP) in Indonesia do not provide a description of evidence. However, Article no 183 of the KUHAP states that judges cannot convict a defendant unless they have the strong belief that a crime has taken place and that the accused in fact committed it. This strong belief must be supported by at least two 'valid pieces of evidence'. Valid pieces of evidence as mentioned in Article 184 are: witness testimony, expert testimony, documents, circumstantial evidence, and testimony of the accused.

Medical records can be used as evidence in cases of malpractice, particularly as evidence that the patients have in fact received treatment. Medical records are the chronological record of the aid, care, and treatment that patients have received while engaging health services. Nowadays, developments in record keeping in the medical/health field mean that activities are not only written on paper, but are recorded in computers, microfilm, vocal cords and others. ${ }^{6}$ According to the Regulation of the Minister of Health Number 269/Menkes/PER/2008, Article 2: Medical records must be made complete and clear, either in writing or electronic. The Law of the Republic of Indonesia, Number 11, Year 2008 on Information and Electronic Transactions is the first piece of legislation to regulate the field of information technology (IT). It's grasp is very broad and many aspects in the field of Information and Electronic Transactions fall under its ambit. The use of IT is a necessity in the world of health care services including Electronic Medical Records, however many health professionals and managers of health-care facilities are hesitant to use it in the absence of a governing law specifically regulating its use. ${ }^{7}$

Although cyber activities are virtual, it is capable of forming the basis of a legal action. Legally, for cyber space, it is no longer proper to categorize something according to the size and qualifications of conventional law to be used as objects and actions, because the process will be too difficult and the activity may escape being covered by the law. Cyber activities are virtual activities that have real life impacts although the evidence is in electronic form. Thus, perpetrators of cyber crime must be regarded the same as those people who have committed a crime in the real world. ${ }^{8}$ Medical records can be used for the benefit of the court process. Judges and lawyers are responsible for dealing with any provisions of the legislation governing evidence, in the

\footnotetext{
${ }^{3}$ Gemala Hatta, 1995, "Transisi Rekam Medis ke Era Informasi”, Seminar Nasional Pra Kongres II PORMIKI, DIY

${ }^{4}$ Teguh Wahyono,2006, Etika Komputer dan Tanggung Jawab Profesional dibidang Tehnologi Informasi, Andi Offset, Yogyakarta page .18

${ }^{5}$ JAHIMA, Okt 2006, The Values of Personal Health Records, page. 24.

${ }^{6} \mathrm{http} / / /$ rekammedisugm08.blogspot.com/

${ }^{7}$ billy@informatika-kesehatan.web.id

${ }^{8}$ Jamal Wiwoho, 2012, Materi Kuliah, Model Pengaturan ITE, www.jamalwiwoho.com
} 
absence of any governing provisions on electronic evidence in the Book of the Criminal Law Act. Thus, the evidence in the perspective of the criminal procedural law, is a regulatory requirement that limits the court in an attempt to seek and defend the truth of law enforcement officials who are bound by the provisions and procedures of assessment of evidence prescribed by law.

\section{Research Method}

This research was conducted using normative law analysis. Data analysis employed qualitative method namely, analyzing data based on systematic data analysis gained from library.

\section{Discussion}

Medical records occupy a central position in the system of maintenance and health care and are very important documents because they may indicate the fact that maintenance and health services have been provided by the doctor to the patient at a certain health facility. According to Poernomo ${ }^{9}$, medical records that contain health discipline benefits deserve special attention, especially when considering the principle of informed consent as forming part of the potential circumstantial evidence in the event of a dispute or lawsuit. Nevertheless notes made by an expert can also be regarded as valuable evidence. With regard to evidence in court proceedings, Article 183 of the Republic of Indonesia Law No. 8 of 1981 on Criminal Proceedings states that the judge must not convict a defendant unless they have the strong belief of guilt, based on the findings of two valid pieces of evidence which demonstrate that a crime has taken place and that the accused committed it. Therefore, according to this provision, in any malpractice case, there must be at least two valid pieces of evidence proving guilt. Evidence of health services can be seen in the medical record. The problem is therefore whether the Electronic Medical Record can be used as evidence in criminal proceedings.

The criminal justice system in Indonesia consists of several stages: investigation stage, investigation, prosecution stage and examination stage. All the stages are outlined in Act No. 8 of 1981 on Criminal Proceedings and other laws that specifically regulate the criminal justice system. Electronic evidence is not listed as valid evidence in the KUHAP however sometimes there is disagreement between law enforcement officials as to the validity of electronic evidence. Based on Article 184 of the KUHAP however, legal evidence can be an expert witness, witness statements, letters, instructions and testimony of the defendant. The implementation of the KUHAP should be based on rule of law, which means all law enforcement actions should be based on the legal provisions and the existing legislation. Proof is the most important element in the examination stage as in court proceeding, the process and manner of proving whether the defendant is guilty or not takes place in a trial. The judge role in proof is very important to decide a case. According to Sudikno Mertokusuma as quoted by Anwar (2009): The existence of judges as the law enforcement authority today receives negative perception from the public, this is caused by many decisions made by the judges which do not fulfil public expectations. Another reason is that crimes are more complex in their form these days and many new crimes have not been contemplated by the laws governing criminal acts. ${ }^{10}$ Article 10(1) of Law No. 48 of 2009 on Court Authority provides that the Court is the Judicial Authority to determine whether; the Court is prohibited from refusing to examine where the case is filed based on the proposition that law regulating such cases does not currently exist or is not clear. Article 10(1) therefore means that the judge as the main judicial organ and as judicial executor is obliged to find the appropriate law in a case although the legal provision does not exist or not clear. Article 5(1) of Law No. 48 Year 2009 also explains that a Judge and Constitutional Judge shall follow and understand the values of law and justice existing in the society. Evidence in electronic form has not been recognized as evidence in criminal procedure law. It is suggested that even though the Book of Criminal Code has not regulated the use of electronic forms of evidence, law enforcement officials should seek

\footnotetext{
${ }^{9}$ Bambang Poernomo, Tanpa Tahun, Hukum Kesehatan, Yogyakarta, Magister Managemen Rumah Sakit, UGM, page.114.

${ }^{10}$ Yesmil Anwar - Adang ,2009, Sistem Peradilan Pidana, Widya Padjadjaran, Bandung, page 218
} 
other regulations as a legal basis for the possibility of using Electronic Medical Records as evidence in malpractice cases. As stated in the Article 2 of the Minister of Health Regulation Number 269 Year 2008: Medical records must be made clear and complete both in writing or electronic. Electronic Medical Records are not regulated further in that article. Implementation of electronic information technology is set on Article 1(4) which states that an Electronic Document is any electronic information created, forwarded, sent, received, or stored in analog, digital, electromagnetic, optical, or similar, which can be viewed, displayed and/or heard through a computer or other electronic systems. Furthermore, under Article 5 of the Law on Information Technology, electronics are regulated as follows:

1. Electronic Information and/or Electronic Document and/or prints with a valid legal evidence.

2. Electronic Information and/or Electronic Document and/or prints as described in (1) an extension of the valid evidence in accordance with the existing Procedure Law in Indonesia

Based on this rule, the judge may reason that electronic medical records are included in the definition of electronic documents and can therefore be used as evidence if one of the existing evidences is in the form of Electronic Medical Records in a criminal case. Evidence in digital form also raises concerns of validation when it is sought to be used as evidence, because electronic evidence has specific characteristics compared to nonelectronic evidences; those special characteristics are the form that allows it to be stored in electronic media. Furthermore, electronic evidence can easily been tampered with, creating more doubt as to its legitimacy. The United States regulates electronic evidence in the Criminal Procedure Code which provides for evidence to be electronically inserted into the real evidence. This is the same for photos, videos, recordings, and films and allows electronic evidence to be included in real evidence. Some countries such as China, Australia, Japan, and Singapore already have legislation that recognizes electronic data as evidence. Pursuant to the KUHAP, the guidelines and limitation of the roles of the law enforcement officials are regulated as follows:

1. The public prosecutor acts as an officer who is given the authorization to give all efforts to prove that the accused committed the alleged crime.

2. On the other hand defendant or defence attorney has the right to undermine the proof provided by the prosecutor, in such ways that are justified by the legislation.

3. Especially for judges, must be completely aware of and can carefully assess and consider the power of evidence that was found during the trial examination. ${ }^{11}$

However, the use of Electronic Medical Records in criminal case processes can not serve as the sole evidence to determine whether the defendant is guilty or not in case of malpractice. The judge must base their decision on two valid pieces of evidence, in addition to the Electronic Medical Record. $f$ two valid pieces of evidence are found, the judge also needs to be convinced that the Electronic Medical Record is true. The system of proof adopted by the Indonesian criminal justice system is the "negatief wettelijk stelsel" proof system or the "negative proof system" which means that a crime needs to be proved by at least two pieces of valid evidence. Through these, the judge must be convinced that the crime has taken place and the defendant/accused has committed a crime.

\section{Conclusion}

Electronic Medical Records are computer-based information management procedures on the health status and health care of the entire life of an person. Although electronic evidence has not been regulated by the Book of the Law of Criminal Law, it can be used as evidence by relying on other rules. From the contents of the Electronic Medical Record itself, the Electronic Medical Record is considered to be valid evidence under the

\footnotetext{
${ }^{11}$ M. Yahya Harahap,dalam http://fauzanjauhari.blogspot.co.id/2013/11
} 
provisions of Article 5(1) of the Law of the Republic of Indonesia Number 11 Year 2008 concerning Electronic Information and Transactions.

The judge has the ability to decide if there is a minimum of two (2) valid evidences, in addition to the Electronic Medical Record. For the evidence to meet the requirements of the provision, the judge needs to be satisfied that the Electronic Medical Record is true, as the objective in criminal cases is to discover the material truth. Indonesia adopts written laws- laws which have been enacted into legislation. However, electronic evidence has not yet been regulated in the KUHAP. Therefore, it is suggested that the legal basis found in Article 184 of the KUHAP should be revised by adding electronic evidence so that electronic medical records can be used as evidence in the criminal process in Indonesia.

\section{References}

Anwar, Y. \& Adang, (2009), System of Criminal Justice, Bandung, Widya Padjadjaran, Dissertation

Hatta,G. R. (1995), "Medical Record Tramsition in Information Erai", National Seminar Pra Kongres II PORMIKI, DIY.

Ministry of Health Regulation RI No. 269/MenKes/Per/III/2008, about Medical Record. The Act of Republic Indonesia Number. 8 Year 1981. About Criminal Procedural Law the Act of Republic Indonesia Number. 29 Year 2004. About Medical Practices.

The Act of Republic Indonesia Number. 14 Year 2008. About Open Electronic Information the Act of Republic Indonesia Number. 36 Year 2009 about Health.

The Act of Republic Indonesia Number. 44 Year 2009 about Hospital Rumah Sakit. Jamal Wiwoho, 2012, Materi Kuliah, Model Pengaturan ITE, www.jamalwiwoho.com

Wahid, A. \& Labib, M. (2005), Mayantara Criminal, Bandung, Refika Aditama Bambang Poernomo, Health Law Yogyakarta, Magister Managemen Rumah Sakit, UGM.

Wahyono, T. (2006), Etika Komputer dan Tanggung Jawab Profesional dibidang Tehnologi Informasi, Yogyakarta, Andi Offset.

Wisnubroto, A. (2010), Indonesian Criminal Procedural Law Recapitulation in facing Criminal Based on telematica Technology, Desertation, Doctoral Program, Semarang.

JAHIMA, Okt 2006, The Values of Personal Health Records

Wiwoho, J. (2012), ITE Usage Regulation, Lecture Material S3 Law Faculty UNS, Surakarta. Syaiful Bakhri. (2014), Indonesia System of Criminal Justice, Yogyakarta, Pustaka Pelajar. 